\title{
EVALUASI PROGRAM PERBAIKAN JALAN LINGKUNGAN PADA KABUPATEN LOMBOK TIMUR PROVINSI NUSA TENGGARA BARAT
}

\author{
Ni Nyoman Kencanawati ${ }^{1)}$, Muhajirah'1) dan Zainudin ${ }^{2)}$ \\ 1)Magister Teknik Sipil, Universitas Mataram, Mataram, Nusa Tenggara Barat, Indonesia \\ ${ }^{2)}$ Dinas Perumahan dan Permukiman Provinsi NTB, Mataram, Nusa Tenggara Barat, Indonesia \\ Corresponding author : Ni Nyoman Kencanawati \\ E-mail : nkencanawati@unram.ac.id
}

Diterima 04 Oktober 2021, Direvisi 21 November 2021, Disetujui 21 November 2021

\begin{abstract}
ABSTRAK
Perbaikan jalan lingkungan di Kabupaten Lombok Timur merupakan program dari Kementerian PUPR melalui Direktorat Jenderal Cipta Karya yang ditujukan untuk mengurangi kesenjangan antar wilayah, pengentasan kemiskinan, memperbaiki tata kelola pemerintah daerah (kabupaten, kecamatan dan desa) serta memperkuat kelembagaan masyarakat di tingkat desa. Pelaksanaan program ini melibatkan Disperkim Provinsi NTB dan Dinas Cipta Karya PUPR Provinsi NTB sebagai pendamping dan pengawas teknis. Program ini dilaksanaan sejak Tahun 2017 hingga saat ini. Artikel ini bertujuan untuk mengevaluasi pelaksanaan program dan memberikan rekomendasi untuk pelaksanaan pada tahun berikutnya. Wilayah yang menjadi target evaluasi terdapat pada beberapa kecamatan meliputi Kecamatan Pringgasela, Kecamatan Sembalun, Kecamatan Aikmel, Kecamatan Pringgabaya dan Kecamatan Wanasaba. Bila dilihat secara persentase nilai capaian dari pelaksaanaan program, maka diperoleh rata-rata mencapai di atas $80 \%$. Bahkan untuk Kecamatan Priggabaya dan Wanasaba pada Tahun 2020 mencapai 91\% dan 92\% berturut-turut. Selain itu Kecamatan Wanasaba memiliki persentase pencapaian tertinggi yaitu 93\% di Tahun 2020. Pencapaian pelaksaaan menunjukkan persentase yang terus meningkat sehingga tercapai tujuan utama yang dinginkan. Sebagai rekomendasi untuk pelaksanaan tahun ongoing dan tahun selanjutnya maka dalam pelaksanaan sebaiknya melibatkan partisipasi dari masyarakat sehingga program dapat mencapai seluruh daerah yang ditargetkan dan menghasilkan nilai capaian sebesar $100 \%$.
\end{abstract}

Kata kunci: jalan lingkungan; perbaikan; evaluasi; capaian; lombok timur.

\begin{abstract}
The improvement of side roads in East Lombok Regency is a program of the Ministry of PUPR through the Direktorat Jenderal Cipta Karya which is aimed at reducing regional disparities, alleviating poverty, improving local government (district, sub-district, and village), and strengthening community institutions at the village level. The implementation of this program involves the Disperkim Provinsi NTB dan Dinas Cipta Karya PUPR as assistants and technical supervisors. This program has been implemented since 2017 until now. This article aims to evaluate the implementation of the program and provide recommendations for implementation in the following year. The evaluation target areas are located in several sub-districts including Pringgasela, Sembalun, Aikmel, Pringgabaya, and Wanasaba. According to a percentage of the achievement value of program implementation, the average achieved is above $80 \%$. Even for the Districts of Priggabaya and Wanasaba in 2020, it reached $91 \%$ and $92 \%$, respectively. In addition, Wanasaba District has the highest percentage of achievement, which is $93 \%$ in 2020 . The achievement trend increases since the program has been initiated in 2017. As a recommendation for the implementation of the ongoing year and the following year, the implementation should involve the participation of the community. Thus the problems that have occurred so far can be avoided and are expected to reach all targeted areas to produce an achievement value of $100 \%$.
\end{abstract}

Keywords: side roads; repair; evaluation; achievement; east lombok.

\section{PENDAHULUAN}

Permasalahan yang dihadapi di daerah perkotaan maupun pedesaan dapat dilihat dari tingkat pelayanan sarana dan prasarananya yang masih terbatas, dan belum dapat menjangkau seluruh lapisan masyarakat
(Hikmana et al., 2015; Susanto, 2019; Wijaya, 2016). Saat ini, pemerintah Provinsi Nusa Tenggara Barat terus berupaya menyelesaikan permasalahan lingkungan terutama permukiman kumuh. Upaya ini dilakukan untuk memenuhi amanat Undang-undang Nomor 1 
tahun 2011 Tentang Perumahan dan Kawasan Permukiman Pasal 5 Ayat (1) yang menyatakan bahwa "Negara bertanggung jawab atas penyelenggaraan perumahan dan kawasan permukiman yang pembinaanya dilaksanakan oleh pemerintah". Berdasarkan Peraturan Menteri Dalam Negeri Nomor 54 Tahun 2010, tujuan dari penataan perumahan dan permukiman adalah: (1) Memenuhi kebutuhan rumah sebagai salah satu kebutuhan dasar manusia, dalam rangka peningkatan dan pemerataan kesejahtraan manusia, (2) Mewujudkan perumahan dan permukiman yang layak dalam lingkungan yang sehat, aman serasi dan teratur (Indonesia, n.d.; Soesilo, 2002b, 2002a).

$\begin{array}{lrr} & \text { Program } & \text { Pengembangan Infrastruktur } \\ \text { Sosial } & \text { Ekonomi } & \text { Wilayah } \\ \text { PISEW merupakan program yang } & \end{array}$
dilaksanakan untuk mendukung kebijakan pemerintah dalam meningkatkan dan mengembangkan infrastruktur yang mendorong pertumbuhan ekonomi kawasan permukiman di kecamatan, serta meningkatkan kualitas permukiman perdesaan (PUPR Kementerian Pekerjaan Umum dan Perumahan Rakyat, 2016a). Kementerian Pekerjaan Umum dan Perumahan Rakyat (PUPR) turut mendukung pertumbuhan ekonomi perdesaan melalui penyediaan infrastruktur dasar. Salah satunya adalah Program Pengembangan Infrastruktur Sosial Ekonomi Wilayah (PISEW) (PUPR Kementerian Pekerjaan Umum dan Perumahan Rakyat, 2016b) yang dilakukan Kementerian PUPR melalui Direktorat Jenderal Cipta Karya. Program seperti ini umunya bertujuan untuk mengurangi kesenjangan antar wilayah, pengentasan kemiskinan, memperbaiki tata kelola pemerintah daerah (kabupaten, kecamatan dan desa) serta memperkuat kelembagaan masyarakat di tingkat desa (Dewandaru, 2018).

Program Pengembangan Infrastruktur Sosial Ekonomi Wilayah di Kabupaten Lombok Timur memiliki luasan lokasi yang paling tinggi dibandingkan dengan daerah kabupaten/kota yang lain di Pulau Lombok dengan total $38.13 \%$ dari total luasan (PUPR Kementerian Pekerjaan Umum dan Perumahan Rakyat, 2016b). Program ini dimulai sejak Tahun 2017 dengan pengajuan proposal dari masyarakat hingga Tahun 2020 program telah selesai. Program ini diharapkan tetap berlanjut sehingga dapat tercapai tujuan yang diinginkan secara lebih menyeluruh. Tulisan ini bertujuan untuk mengkaji proses pelaksanaan Program Pengembangan Infrastruktur Sosial Ekonomi Wilayah di Kabupaten Lombok Timur pada daerah target dan memberikan rekomendasi pada pelaksanaan program sejenis dimasa mendatang.

\section{METODE}

Metode yang digunakan pada studi ini dalam rangka evaluasi kondisi pelaksanaan dan pembuatan rekomendasi adalah observasi dan wawancara. Observasi dilakukan pada proyek yang dilkasanakan pada daerah target sedangkan wawancara dengan menggunakan Instrument berupa kuisener yang dibagikan pada responden. Responden berasal dari sisi pemerintah pusat dalam hal ini Disperkim Provinsi NTB, Cipta Karya Dinas PUPR Provinsi NTB. Selanjutnya responden juga berasal dari sisi pihak pelaksana dan pengawas lapangan, serta masyarakat sekitar. Total terdapat 90 responden terlibat pada studi ini.

\section{Daerah Target}

Untuk melakukan kajian ini, wilayah yang menjadi target penelitian terdapat pada beberapa kecamatan di wilayah Kabupaten Lombok Timur, di antaranya Kecamatan Pringgasela, Kecamatan Sembalun, Kecamatan Aikmel, Kecamatan Pringgabaya dan Kecamatan Wanasaba. Wilayah target terlihat pada Gambar 1.

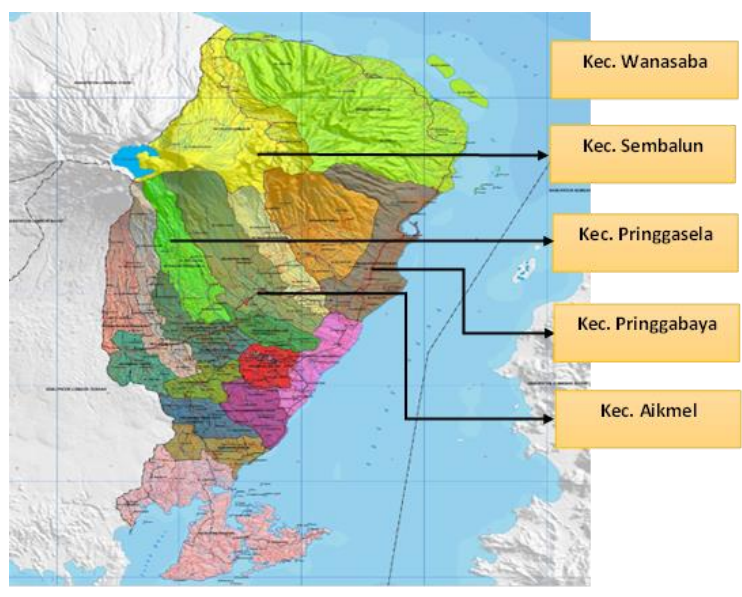

Gambar 1. Lokasi Wilayah (Zainudin, 2021)

Pada kawasan permukiman tersebut memiliki jalan lingkungan yang belum memadai. Hal tersebut diharapkan menjadi perhatian bagi semua pihak untuk meningkatkan kuantitas dan kualitas dalam pelaksanaan Program Pengembangan Infrastruktur Sosial Ekonomi (Sekeon et al., 2019; Shobirin \& Ali, 2019; Valeriani, 2011).

\section{Pelaksanaan dan Pembangunan}

Program Pengembangan Infrastruktur Sosial Ekonomi Wilayah (PISEW) di Kabupaten Lombok Timur merupakan kebutuhan yang mutlak dipenuhi. Infrastruktur seperti jalan sangat dibutuhkan oleh masyarakat sebagai 
penghubung antar lingkungan dan antar desa, karena berdampak langsung dengan aktifitas masyarakat. Beberapa kawasan permukiman memiliki jalan lingkungan yang belum memadai.

Terciptanya kegiatan ini dimulai dari masyarakat dari daerah target mengajukan proposal perbaikan jalan lingkungan untuk kemudian diajukan oleh dewan daerah. Selanjutnay oleh dewan daerah proposal ini diajukan pada Kementerian Pekerjaan Umum dan Perumahan Rakyat (PUPR) melalui Direktorat Jenderal Cipta Karya. Setelah disetujui maka ditentukan konsultan konsultan dan kontraktor yang mendesain dan melaksanakan proyek.

Mitra yang terlibat mencakup:

1. Pihak pertama: Disperkim Provinsi NTB, Dinas Cipta Karya PUPR Provinsi NTB Provinsi NTB dan Balai Prasarana Permukiman Wilayah (BPPW) NTB sebagai: pemilik dan pengawas dari proyek.

2. Pihak Kedua: Masyarakat yang di wakili oleh Kepala Desa dan Kepala Dusun sebagai pihak yang mendapatkan manfaat.

3. Pihak Ketiga: Pihak ketiga adalah konsultan dan kontraktor yang mendesain dan melaksanakan proyek.

Bentuk kegiatan dimulai dari Tujuan akhir program PISEW ini yakni terbangunnya infrastruktur dasar skala wilayah kecamatan, berupa infrastruktur perhubungan/transportasi sebagai infrastruktur pendukung pemasaran hasil masyarakat dan diharapkan dapat mendukung sektor lainnya seperti kesehatan, pendidikan, dan pariwisata.

\section{HASIL dan PEMBAHASAN Kecamatan Aikmel}

Dari tahun 2017 sampai dengan tahun 2020 pemerintah khususnya Pemerintah Propinsi NTB melaksanakan 153 paket program PISEW dengan total anggaran 30,6 miliar rupiah dan dapat meningkatkan kualitas 48,2 km jalan lingkungan. Keberhasilan ini disebabkan karena masyarakat pada Kecamatan Aikmel ini sangat menerima dan terbuka terhadap program PISEW.

Secara umum kegiatan yang dilakukan pada Kecamatan Aikmel sama dengan kecamatan target lainnya. Kegiatan diawali dengan penyusunan data kondisi geografis dan geometrik jaringan jalan melalui kegiatan pengumpulan data dan survey lapangan. Selanjutnya kegiatan perencanaan berupa perkiraan kebutuhan biaya, bahan, dan waktu pelaksanaan. Kegiatan berikutnya berupa pelaksanaan dan evaluasi yang meliputi operasi pekerjaan yang sedang berjalan, monitoring dan pengendalian, yang dilakukan oleh konsultan, kontraktor,dan pengawas lapangan.

Sebelum program dilaksanakan di beberapa titik lokasi kendaraan roda 3 dan 4 tidak dapat melewati jalan. Namun setelah Program PISEW terlaksana, masyarakat merasa lebih efektif dan efisien dalam menjalankan aktivitas dan distribusi hasil bumi mereka. Gambar 2 dan 3 menunjukkan kondisi sebelum dan sesudah pembangunan jalan lingkungan pada Dusun Cepak Daya dan Dusun Tabi'in pada Kecamatan Aikmel.

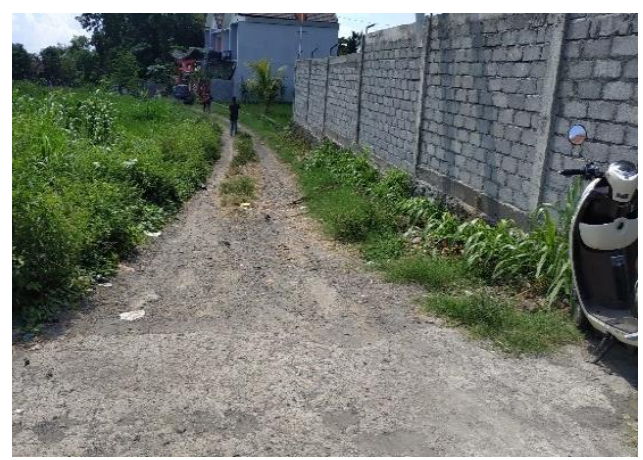

(a) Sebelum

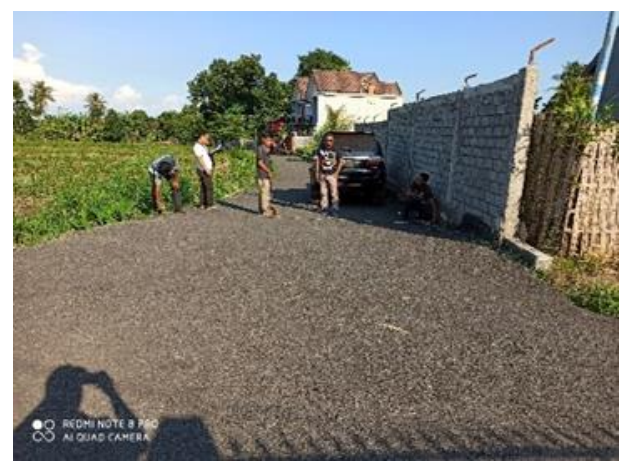

(b) Sesudah

Gambar 2. Gambaran lokasi jalan lingkungan Dusun Cepak Daya Kecamatan Aikmel sebelum (a) dan sesudah (b) pelaksanaan PISEW (Zainudin, 2021).

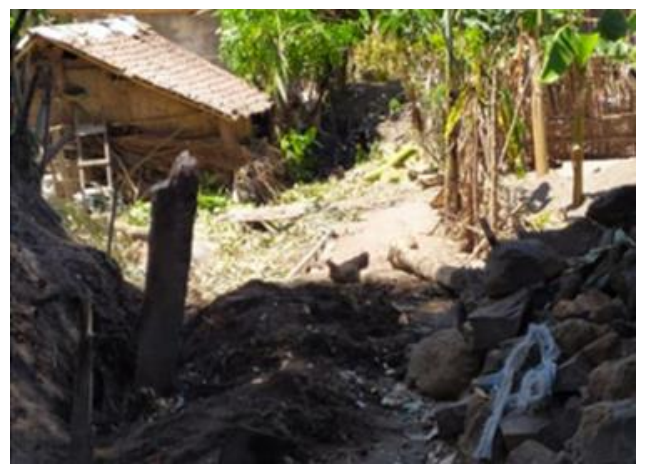

(a) Sebelum 


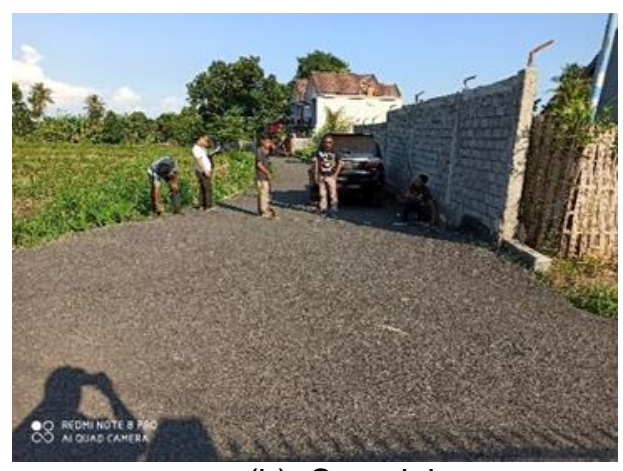

(b) Sesudah

Gambar 3. Gambaran lokasi jalan lingkungan Dusun Tabi'in Kecamatan Aikmel sebelum (a) dan sesudah (b) pelaksanaan PISEW

(Zainudin, 2021).

\section{Kecamatan Pringgabaya}

Dari tahun 2017 sampai dengan tahun 2020, Pemerintah Propinsi NTB telah melaksanakan 78 paket program PISEW dengan total anggaran 15,6 miliar rupiah dan dapat meningkatkan kualitas $24,5 \mathrm{~km}$ jalan lingkungan pada Kecamatan Pringgabaya. Berdasarkan pengamatan dilapangan setelah dilaksanakan program PISEW oleh pemerintah, selain dapat meningkatkan fasilitas infrastruktur yang merata di Kecamatan Pringgabaya, juga dapat meningkatkan peluang lapangan kerja karena kelancaran transportasi.

Hasil wawancara dengan masyarakat setempat, bahwa pelaksanaan program PISEW ini sangat di dukung penuh oleh seluruh masyarakat. Selain dapat memperbaiki distribusi pendapatan juga tumbuh industri pengolahan ikan, sehingga manfaat yang dirasakan sangat terasa pada aktivitas seharihari. Gambar 4 dan 5 berturut-turut menunjukkan kondisi sebelum dan sesudah pembangunan jalan lingkungan pada Dusun Bagek Kedok dan Dusun Gubug Montong Kecamatan Priggabaya.

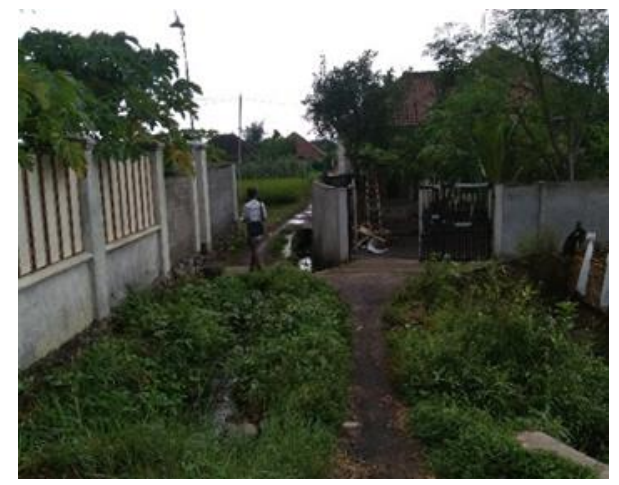

(a) Sebelum

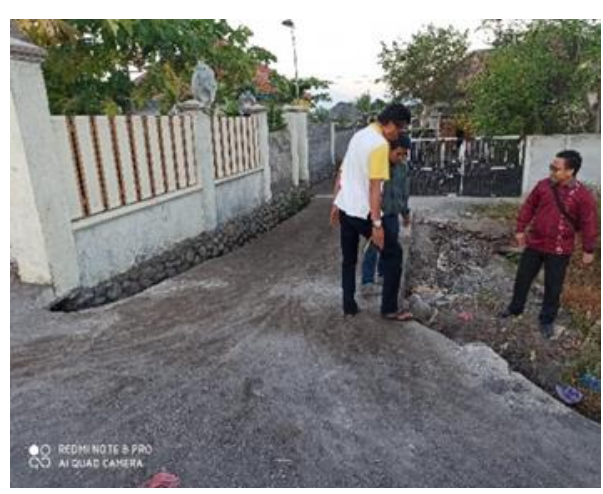

(b) Sesudah

Gambar 4. Gambaran lokasi jalan lingkungan Dusun Bagek Kedok Kecamatan Priggabaya sebelum (a) dan sesudah (b) pelaksanaan PISEW (Zainudin, 2021).

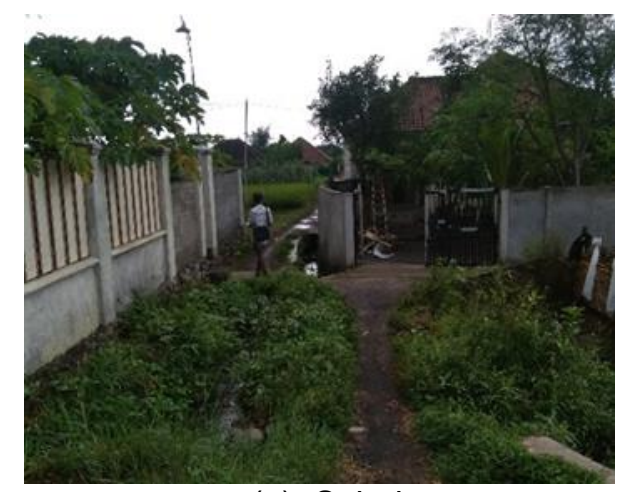

(a) Sebelum

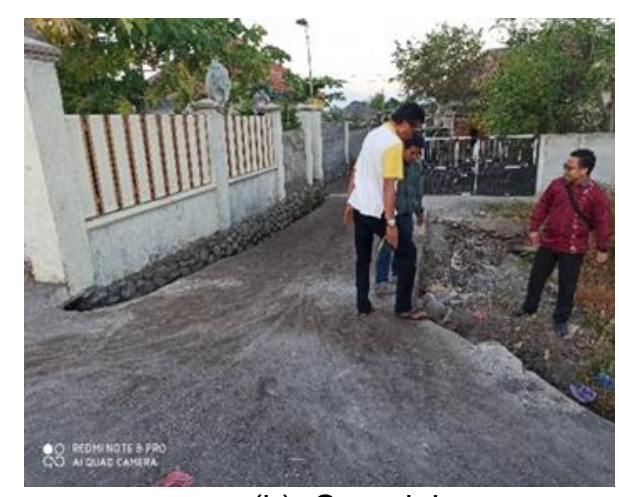

(b) Sesudah

Gambar 5. Gambaran lokasi jalan lingkungan Dusun Gubug Montong Kecamatan

Priggabaya sebelum (a) dan sesudah (b) pelaksanaan PISEW (Zainudin, 2021).

\section{Kecamatan Pringgasela}

Sejak Tahun 2017 Pemerintah Propinsi NTB melaksanakan 150 paket program PISEW dengan total anggaran 30 miliar rupiah dan dapat meningkatkan kualitas jalan lingkungan sepanjang 47,3 km. Secara khusus, Kecamatan Pringgasela merupakan destinasi wisata dan usaha kecil menengah (UKM) kain tenun tradisional Pulau Lombok.

Pelaksanaan program PISEW ini di sambut sangat baik dan terbuka oleh 
masyarakat. Hasil wawancara menunjukkan bahwa setelah di laksanakan program ini terjadi peningkatan jumlah pengunjung obyek wisata dimana salah satunya dipengaruhi oleh akses jalan yang dilewati pengunjung lebih mudah akibat adanya program peningkatan jalan ini. Selain itu tingkat keamanan pengunjung wisata menjadi lebih terjamin, mempersingkat waktu tempuh ke tempat tujuan obyek wisata, dan menghemat biaya operasional.

Program PISEW ini juga berpengaruh pada industri-industri kecil lainnya selain tenun sehingga meningkatkan distribusi pendapatan masyarakat setempat.

Hasil dokumentasi lapangan sebelum dan setelah pelaksanaan program PISEW untuk Kecamatan Pringgasela disajikan pada Gambar 6 dan 7 berturut-turut untuk Dusun Dasan Sadar dan Dusun Timuk Belimbing Selatan.

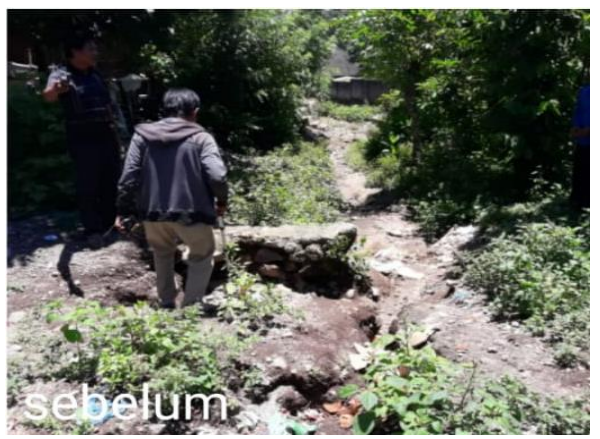

(a) Sebelum

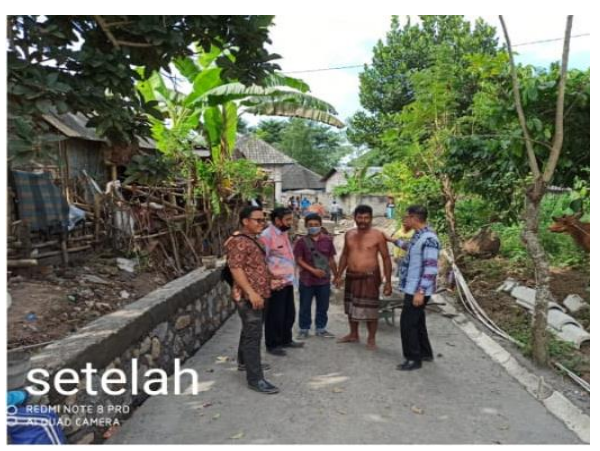

(b) Sesudah

Gambar 6. Gambaran lokasi jalan lingkungan Dusun Dasan Sadar Kecamatan Pringgasela sebelum (a) dan sesudah (b) pelaksanaan PISEW (Zainudin, 2021).

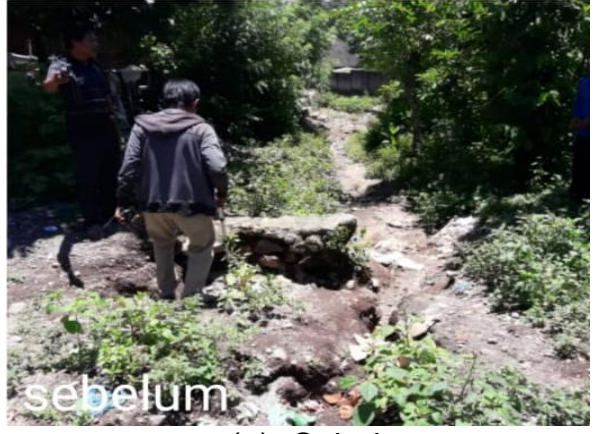

(a) Sebelum

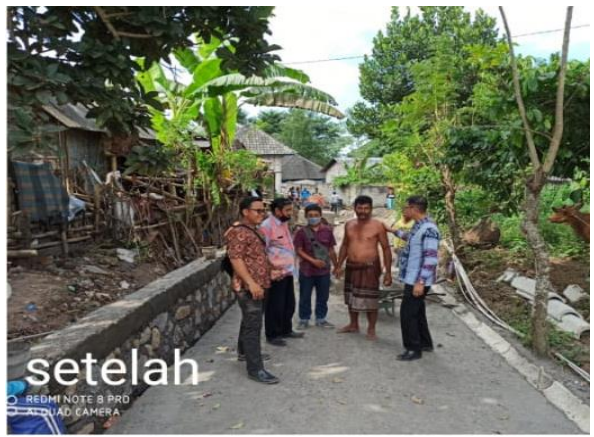

(b) Sesudah

Gambar 7. Gambaran lokasi jalan lingkungan Dusun Timuk Belimbing Selatan Kecamatan

Pringgasela sebelum (a) dan sesudah (b) pelaksanaan PISEW (Zainudin, 2021).

\section{Kecamatan Wanasaba}

Secara umum kondisi jalan di Desa Wanasaba terdapat banyak kerusakan sehingga warga terbatas dalam mobilisasi. Demikian pula jumlah masih sangat kurang seperti yang dirasakan masyarakat setempat. Melalui program PISEW ini, fasilitas infrastruktur sudah dapat menjadi lebih baik. Sejak Tahun 2017 sampai dengan Tahun 2020 Pemerintah Propinsi NTB telah berhasil menyelesaikan 66 paket program PISEW dengan total anggaran 13,2 miliar rupiah dan dapat meningkatkan kualitas seoanjang 20,8 $\mathrm{km}$ jalan lingkungan.

Berdasarkan wawancara dengan perangjat desa, penerimaan masyarakat dengan program PISEW ini sangat baik. Sebagian besar masyarakat di Kecamatan Wanasaba bermata pencaharian menjadi petani dengan lahan pertanian yang masih sangat luas. Dengat adanya program ini maka akses jalan masyarakat untuk mengangkut hasil panen sawah lebih mudah. Akses jalan menuju lokasi sekolah pun sudah bisa terealisasi dengan baik sehingga memudahkan anak-anak bersekolah baik dengan berjalan kaki maupun bersepeda. Selanjutnya dengan adanya peningkatan jalan lingkungan dapat menghilangkan kesan wilayah kumuh pada Kecamatan Wanasaba. Gambar 8 dan 9 berturut-turut menunjukkan kondisi sebelum 
dan sesudah pembangunan jalan lingkungan pada Dusun Kebon Ayu dan Dusun Tembeng Putik Bongkol pada Kecamatan Wanasaba.

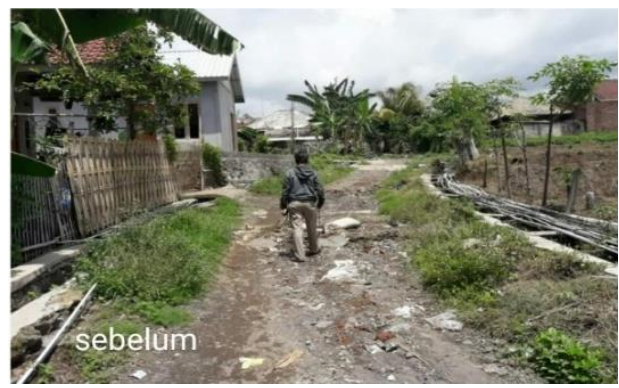

(a) Sebelum

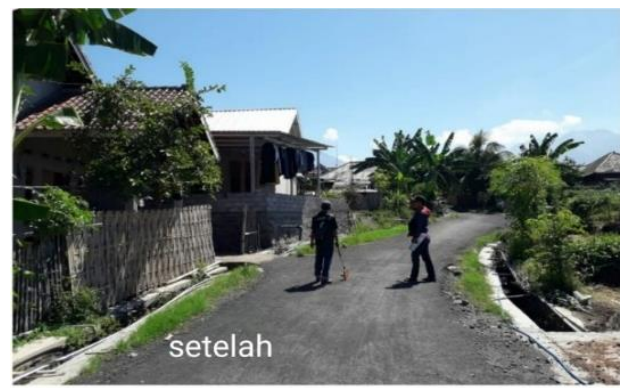

(b) Sesudah

Gambar 8. Gambaran lokasi jalan lingkungan Dusun Kebon Ayu Kecamatan Wanasaba sebelum (a) dan sesudah (b) pelaksanaan PISEW (Zainudin, 2021).

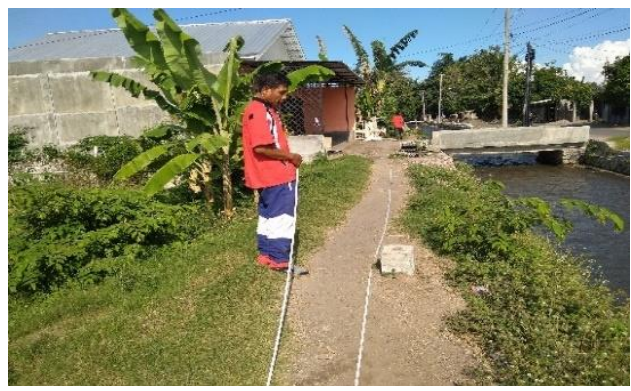

(a) Sebelum

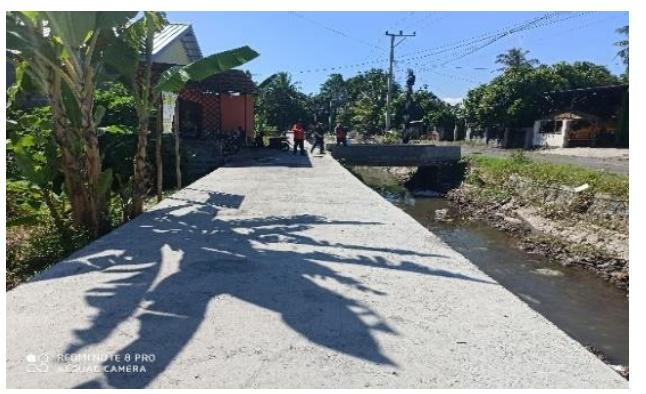

(b) Sesudah

Gambar 9. Gambaran lokasi jalan lingkungan Dusun Tembeng Putik Bongkol Kecamatan Wanasaba sebelum (a) dan sesudah (b) pelaksanaan PISEW (Zainudin, 2021).

\section{Kecamatan Sembalun}

Pekerjaan masyarakat yang paling banyak di Kecamatan Sembalun adalah perkebunan dan pertanian. Selain dari itu Kecamatan Sembalun merupakan destinasi wisata dunia yang sering dituju turis lokal dan mancanegara. Perogram pembangunan untuk jalan lingkungan dari tahun 2017 sampai dengan tahun 2020 telah menyelesaikan 21 paket dengan total anggaran 4,2 miliar rupiah dan dapat meningkatkan kualitas $6,6 \mathrm{~km}$ jalan lingkungan. Ketercapaian infrastruktur jalan lingkungan masih cukup kurang kalau di bandingkan dengan kecamatan-kecamatan yang lain di wilayah Kabupaten Lombok Timur, disebabkan karena program pemerintah dari tahun 2017 sampai dengan tahun 2020 ini diperioritaskan kepada pembukaan jalan nasional di wilayah Kecamatan Sembalun.

Program pemerintah untuk jalan lingkungan mulai lebih di prioritaskan pada tahun 2021. Program PISEW yang terealisasi sampai saat ini sudah mampu memenuhi kebutuhan infrastruktur di wilayah-wilayah permukiman. Program PISEW ini sangat didukung penuh oleh masyarakat karena mendukung daerah mereka dalam menjadi destinasi wisata. Wisatawan menjadi lebih mudah menuju obyek-obyek wisata, tumbuh dan berkembanya industri-industri kecil, seperti pengolahan kopi khas Sembalun, pengolahan perkebunan strawberi, bawang, melon, wortel, dan lain sebagainya. Gambar 10 dan 11 berturut-turut menunjukkan kondisi sebelum dan sesudah pembangunan jalan lingkungan pada Dusun Baret dan Dusun Batu Jalik Kecamatan Sembalun.

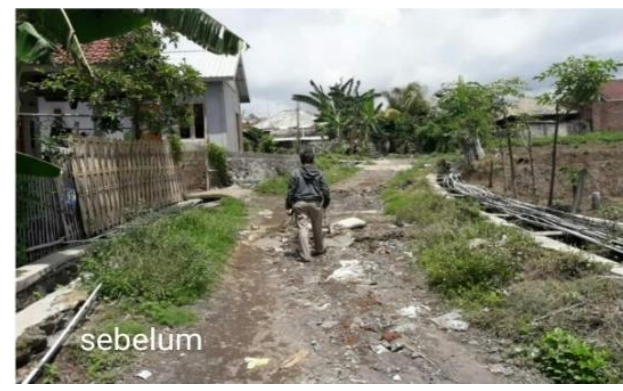

(a) Sebelum

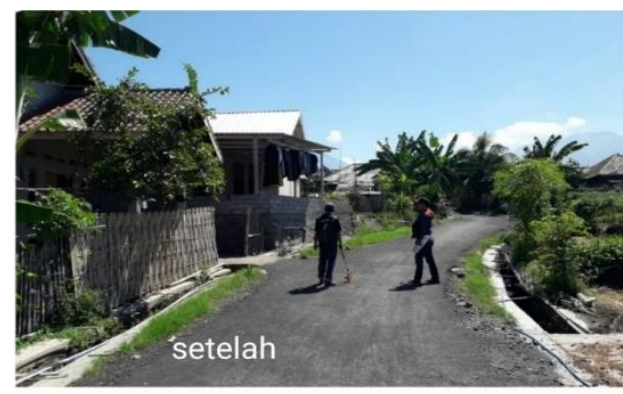

(b) Sesudah

Gambar 10. Gambaran lokasi jalan lingkungan Dusun Baret Kecamatan Sembalun sebelum 
(a) dan sesudah (b) pelaksanaan PISEW (Zainudin, 2021).

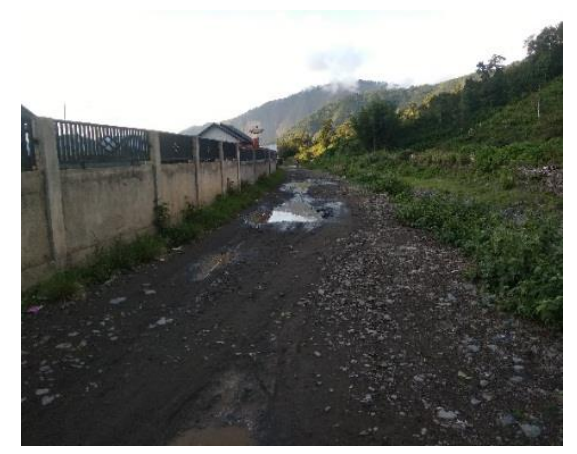

(a) Sebelum

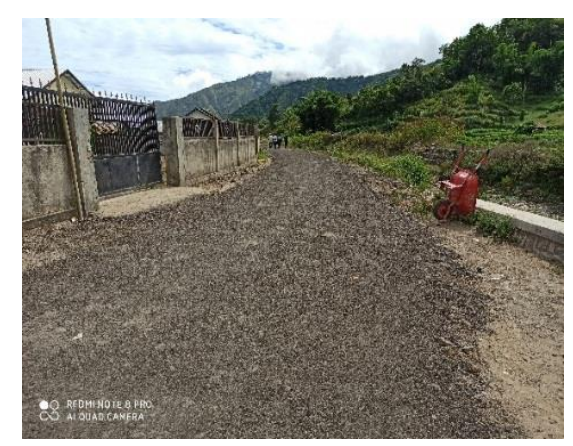

(b) Sesudah

Gambar 11. Gambaran lokasi jalan lingkungan Dusun Batu Jalik Kecamatan Sembalun sebelum (a) dan sesudah (b) pelaksanaan PISEW (Zainudin, 2021).

\section{Kajian Pelaksanaan Program PISEW}

Gambar $\quad 12$ menunjukkan

perbandingan antara target dan capaian dari program pembangunan jalan sejak tahun 2017sampai 2020 pada enam kecamatan pada Kabupaten Lombok Timur. Target program PISEW jalan lingkungan dihitung berdasarkan hasil rekapitulasi panjang jalan usulan masyarakat pada Dinas Perumahan dan Permukiman Provinsi NTB pada tahun yang bersangkutan. Sedangkan progres capaian dihitung berdasarkan rekapitulasi panjang jalan yang dilaksanakan tiap tahun. Dengan demikian data persentase capaian dapat dikalkulasi berdasarkan perbandingan jumlah panjang jalan yg dikerjakan dengan jumlah panjang jalan yg diusulkan pada tahun yang bersangkutan.

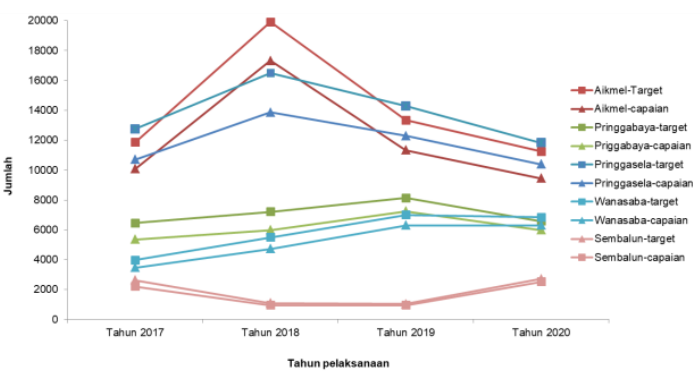

Gambar 12. Target dan capaian program Tahun 2017-2020

Bila dilihat secara persentase nilai capaian dari pelaksaanaan program, maka diperoleh rata-rata mencapai diatas $80 \%$. Bahkan untuk Kecamatan Priggabaya dan Wanasaba pada Tahun 2020 mencapai 91\% dan $92 \%$ berturut-turut. Selain itu Kecamatan Wanasaba memiliki persentase pencapaian tertinggi yaitu $93 \%$ di Tahun 2020 . Pencapaian pelaksaaan menunjukkan persentase yang terus meningkat seperti yang terlihat pada Gambar 13. Gambar ini menunjukkan persentase capaian per kecamatan sejak Tahun 2017-2020.

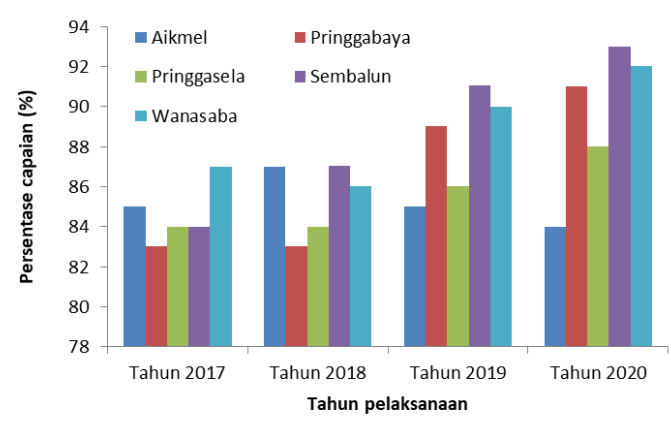

Gambar 13. Persentase capaian per kecamatan sejak Tahun 2017-2020

Pada saat pelaksaaan pembangunan jalan lingkungan, terdapat beberapa kendala seperti yang disampaikan sebagai berikut.

a. Aspal, semen atau bahan-bahan pembuatan jalan yang rawan pencurian.

b. Banyak kendaraan yang melewati jalan yang belum cukup umur untuk dilewati.

c. Pembangunan menyebabkan kemacetan lalu lintas eksisting.

d. Membutuhkan material alam dalam jumlah yang banyak dengan demikian banyak tebing-tebing yang dikeruk untuk diambil tanahnya

Namun setelah terbangunnya jalan lingkungan, banyak keuntungan yang dirasakan warga masyarakat, sebagaimana disampaikan berikut ini.

a. Membantu akses masyarakat menjadi lebih mudah sehingga mendukung taraf 
perekonomian, kesehatan, dan pendidikan masyarakat.

b. Keamanan pengguna jalan lebih terjamin.

c. Mempersingkat waktu tempuh

d. Penghematan biaya operasional (khusus untuk guide tour).

e. Menurunkan angka kecelakaan.

f. Kendaraan lebih tahan lama.

Sebagai rekomendasi untuk pelaksanaan tahun ongoing dan tahun selanjutnya maka pembangunan jalan ini sebaiknya dapat melibatkan partisipasi dari masyarakat. Dengan demikian masyarakat merasa bahwa program ini adalah juga dari mereka sehingga masalah pencurian, kemacetan, penggunaan jalan sebelum waktunya, dan masalah lainnya dapat dihindari. Dengan demikian diharapkan program ini dapat mencapai seluruh daerah yang ditargetkan sehingga menghasilkan nilai capaian sebesar $100 \%$.

\section{SIMPULAN DAN SARAN}

Program Pengembangan Infrastruktur Sosial Ekonomi Wilayah (PISEW) khususnya di Kabupaten Lombok Timur merupakan kebutuhan yang mutlak dipenuhi. Infrastruktur jalan pra-perbaikan kurang dapat menunjang aktifitas masyarakat.

Bila dilihat secara persentase nilai capaian dari pelaksaanaan program, maka diperoleh rata-rata mencapai diatas 80\%. Bahkan untuk Kecamatan Priggabaya dan Wanasaba pada Tahun 2020 mencapai 91\% dan $92 \%$ berturut-turut. Selain itu Kecamatan Wanasaba memiliki persentase pencapaian tertinggi yaitu 93\% di Tahun 2020. Pencapaian pelaksaaan menunjukkan persentase yang terus meningkat sejak Tahun 2017 sampai 2020.

Sebagai rekomendasi untuk pelaksanaan tahun ongoing dan tahun selanjutnya maka dalam pelaksanaan sebaiknya melibatkan partisipasi dari masyarakat. Dengan demikian masalah yang terjadi selama ini dapat dihindari dan diharapkan dapat mencapai seluruh daerah yang ditargetkan sehingga menghasilkan nilai capaian sebesar $100 \%$.

\section{DAFTAR RUJUKAN}

Dewandaru, D. S. (2018). PENENTUAN PRIORITAS PEMBANGUNAN JALAN DESA MENGGUNAKAN RURAL ACCESS INDEX (PRIORITY ASSESSMENT FOR RURAL ROAD DEVELOPMENT USING RURAL ACCESS INDEX). Jurnal Jalan-Jembatan, 35(2), 114-125.
Hikmana, A. A., Djakfar, L., \& Suharyanto, A. (2015). Evaluasi Efektifitas Implementasi Lajur Sepeda Motor (Studi Kasus Jalan Raya Darmo Kota Surabaya). Rekayasa Sipil, 8(3), 158-165.

Indonesia, U.-U. N. (n.d.). Peraturan Menteri Dalam Negeri Nomor 54 Tahun 2010 tentang Pelaksanaan Peraturan Pemerintah Nomor 8 Tahun 2008 tentang Tahapan. Tata Cara Penyusunan, Pengendalian, Dan Evaluasi Pelaksanaan Rencana Pembangunan Daerah.

PUPR Kementerian Pekerjaan Umum dan Perumahan Rakyat. (2016a). Panduan Pembangunan Jalan Perdesaan.

PUPR Kementerian Pekerjaan Umum dan Perumahan Rakyat. (2016b). Pengembangan Infrastruktur Sosial dan Ekonomi Wilayah (PISEW).

Sekeon, G. S., Makarau, V. H., \& Van Rate, J. (2019). ANALISIS INFRASTRUKTUR KAWASAN INDUSTRI DI KECAMATAN KEMA DAN KAUDITAN. SPASIAL, 6(3), 600-608.

Shobirin, M., \& Ali, H. (2019). Strategi Pengembangan Infrastruktur dalam Meningkatkan Pelayanan Penumpang di Bandar Udara Internasional Soekarno Hatta Cengkareng. Jurnal Ekonomi Manajemen Sistem Informasi, 1(2), 155168.

Soesilo, I. N. (2002a). Manajemen Stratejik di Sektor Publik (Pendekatan Praktis) Buku II. Jakarta: FE UI.

Soesilo, I. N. (2002b). Reformasi Pembangunan Perlu Pendekatan Manajemen Strategik, Buku I. Jakarta: Universitas Indonesia.

Susanto, A. (2019). Strategi Pengelolaan Wilayah Pesisir Kecamatan Kuala Jelai Kabupaten Sukamara Berbasis Integrated Coastal Zone Management (ICZM). Jurnal IImiah Samudra Akuatika, 3(2), 21-30.

Valeriani, D. (2011). Analisis Pengaruh Kebijakan Infrastruktur Terhadap Pendapatan Perkapita Masyarakat Kabupaten Bangka Provinsi Kepulauan Bangka Belitung. EQUITY, 1(5).

Wijaya, D. W. (2016). Perencanaan Penanganan Kawasan Permukiman Kumuh (Studi Penentuan Kawasan Prioritas untuk Peningkatan Kualitas Infrastruktur pada Kawasan Pemukiman Kumuh di Kota Malang). Jurnal IImiah Administrasi Publik, 2(1), 1-10.

Zainudin. (2021). Kajian Pelaksanaan Program Pengembangan Infrastruktur Sosial Ekonomi Wilayah (Pisew) Untuk Jalan Lingkungan Di Kabupaten Lombok Timur. Universitas Mataram. 